\title{
The functional power of the CPLP in the framework ok development cooperation in food security and nutrition (FSN)
}

\author{
O poder funcional da CPLP no quadro da cooperação em segurança alimentar e nutricional (SAN)
}

\author{
Manuel Lapão \\ Secretariado Executivo da Comunidade de Países de Língua Portuguesa \\ Rua de S. Mamede (ao Caldas), nº 21 - 1100 - 533 Lisboa, Portugal
}

\begin{abstract}
The Community of Portuguese Speaking Countries (CPLP), about to celebrate its twenty year of existence, was born to preserve the language and a common cultural heritage and has been gradually strengthening other policy dimensions which have led to increased visibility. The cooperation in the areas of Health and Food and Nutrition Security (SAN) is such an example. In fact, the "Food Security and Nutrition Strategy (ESAN-CPLP)", adopted in 2011, is a real and operational tool to improve levels of human development in the member states of the CPLP, and is recognized in international fora as an example of good practice by partners such as the European Union, while also being perfectly aligned with the U.N.'s Goals of Sustainable Development.

Despite the unique role of the CPLP and its potential functional power in the framework of international cooperation, some threats have emerged, preventing its further affirmation, namely the assertion of a clear political will by the member states. Despite the gap between the present CPLP and the Agostinho da Silva's dream of creating a true Lusophone community, its contemporary role and potential is quite clear, and outstanding are the efforts to establish in its framework the Human Right to Adequate Food.
\end{abstract}

Keywords: CPLP, Food and Nutritional Security, Cooperation.

\section{Resumo}

A Comunidade dos Países de Língua Oficial Portuguesa (CPLP), prestes a celebrar os seus 20 anos de existência, nascida para defesa da língua e do património cultural comum, tem vindo gradualmente a reforçar outras dimensões de intervenção nas quais vem alcançando crescente visibilidade. A Cooperação nas áreas da Saúde e da Segurança Alimentar e Nutricional (SAN) são disso exemplo. Na realidade, a sua "Estratégia de Segurança Alimentar e Nutricional (ESANCPLP)", aprovada em 2011, é um instrumento real e operacional para aumentar os níveis de desenvolvimento humano nos Estados membros da CPLP, sendo reconhecida em fóruns internacionais como um exemplo de boas práticas por parceiros como a União Europeia, estando ainda perfeitamente alinhada com os Objetivos do Desenvolvimento Sustentável.

Não obstante o papel único da CPLP e o seu potencial poder funcional no quadro da cooperação internacional, algumas ameaças se colocam, impedindo a sua maior afirmação, nomeadamente a afirmação de uma vontade política mais clara por parte dos Estados membros.

Não obstante a distância que separa a CPLP atual do sonho de Agostinho da Silva, de criação de uma verdadeira comunidade lusófona, é hoje inequívoco o seu papel e potencial, destacando-se o esforço envidado para consagrar no seu espaço o racional do Direito Humano à Alimentação Adequada.

Palavras-chave: CPLP, Segurança Alimentar e Nutricional, Cooperação 
If countries are joined together grounded by linguistic and cultural affinities, nothing is more natural than for the Portuguese Speaking Countries to unite in a common project for the defence of the language and, gradually, to encourage development cooperation at all levels. If there was any peculiarity as to the creation of the Community of Portuguese Speaking Countries (CPLP), it can only be due to the late birth of the organization. The creation of CPLP was, therefore, a historical inevitability.

The CPLP was created on 17 July 1996 and since that date it has coherently and consistently strengthened the ties among member States which constitute, in the words of the Portuguese philosopher Agostinho da Silva, a "linguistic board of Portuguese speaking people, similar to the boards that form planet earth and that played the basis of the creation of a Community".

Although CPLP is still short of the dream of Agostinho da Silva - because it is not yet a real Portuguesespeaking community - it remains a project in which its member States should continue to invest as a strategic design.

On the verge of celebrating its twentieth anniversary in July 2016, the CPLP should continue to strengthen from a bottom-up perspective, at the level of civil society, promoting the sense of a common Lusophone citizenship and strengthening cooperation for sustainability and human development.

The Constitutive Declaration of CPLP resumes this initial dream and from "perennial" values such as Peace, Democracy, Rule of Law, Human Rights, Development and Social Justice, establishes a concern with the collective future of its member States, pledging the strengthening of solidarity and cooperative bonds that unite and promote initiatives of economic and social development of their peoples.

But what does this organization stands for and what is its functional power in the context of international relations?

In this regard, one can consider the theory that power is often in possession of small States and reflected by the grasp of a strategic geographic situation, access to sources of rare minerals and energy sources like oil, elements that are indispensable to the operation of the international systems and thus give the holders the ability to disrupt such systems.

And how can developmental cooperation in context of the CPLP contribute to this aim?

In the last five years, the power exercised by the pillar of developmental cooperation has extended the range of its interventions and is increasingly harmonised with the development priorities of the member States complied with the Constitutive Declaration. Such dynamism
Se os países se unem, desde logo, por afinidades linguísticas e culturais, nada de mais natural que os Países de Língua Portuguesa se unissem num projeto comum - para a defesa da língua, desde logo, e, gradualmente, para cooperarem aos mais diversos níveis. Se estranheza pode haver quanto à criação da Comunidade dos Países de Língua Portuguesa (CPLP), decorrerá somente do facto de ter nascido tão tarde. A criação da CPLP foi, portanto, uma inevitabilidade histórica.

No dia 17 de Julho de 1996 nasce então a CPLP e, desde essa data, que de forma coerente e consequente, se vem assistindo ao reforço dos laços entre os Estados membros que constituem, nas palavras do Filósofo Agostinho da Silva, uma "placa linguística de povos de língua portuguesa - semelhante às placas que constituem o planeta e que jogam entre si a base da criação de uma comunidade".

Se bem que a CPLP esteja ainda aquém do sonho de Agostinho da Silva - pois não é ainda uma verdadeira comunidade lusófona - nem por isso deixa de ser um projeto em que os seus Estados membros devam continuar a apostar enquanto desígnio estratégico.

Ao celebrar os seus 20 anos, em julho de 2016, a CPLP deverá continuar a fortalecer-se, numa perspetiva de baixo para cima, ao nível da sociedade civil, promovendo o sentido de uma cidadania lusófona e reforçando a cooperação para o desenvolvimento sustentável e humano que, mais do que juntar, une, por concertação e cooperação os nossos Estados.

A Declaração constitutiva da CPLP retoma esse sonho inicial e partindo de "valores perenes" como a Paz, Democracia e Estado de Direito, Direitos Humanos, Desenvolvimento e Justiça Social", estabelece uma preocupação com o "futuro coletivo dos seus Países", comprometendo-se a "reforçar os laços de solidariedade e de cooperação que os unem, conjugando iniciativas para a promoção do desenvolvimento económico e social dos seus Povos e para a afirmação e divulgação cada vez maiores da Língua Portuguesa.

Mas o que representa hoje esta organização e qual o seu poder funcional no contexto das Relações Internacionais?

A este propósito, considera a teoria que o poder funcional está frequentemente na posse dos pequenos estados e que se traduz pela detenção de uma situação geográfica estratégica, acesso a fontes de minerais raros e fontes de energia como o petróleo, elementos que são indispensáveis ao funcionamento dos sistemas internacionais e que, portanto, também dão aos seus detentores a capacidade de "disfuncionar" tais sistemas.

E como pode a cooperação em contexto da CPLP contribuir para tal desiderato?

$\mathrm{O}$ vigor evidenciado pelo pilar da Cooperação que, nos 
is evidenced by the completion of more than 15 sectoral ministerial meetings in different areas of intervention. Effectively, the last years of implementation of the Cooperation Indicative Plan of the CPLP (PIC) seem to show a positive momentum and a strengthening of the strategic importance of the development cooperation pillar while operating as an instrument of political dialogue within the community. This dynamic appears to be accompanied by the growing visibility and recognition of the role of the CPLP in areas of development cooperation such as Health, Food Security and Nutrition (FSN), Labour and Social affairs (in particular in the field of the fight against child labour), human rights, seas and energy. However, the progresses made were asymmetric in terms of technical areas, both with regard to ownership and to strengthening the joint responsibility of the member States.

Despite the maturing of the intervention capacity of the Focal Points of Cooperation (PFC), greater stabilization of coordination mechanisms and harmonization of agendas with the focal points of the sectoral ministerial meetings and respective Permanent Technical Secretariats (StP) is still required. The effort to promote dialog among the offices of sectoral ministerial meetings, the Standing Committee for Consultation, the meeting of Focal Points of Cooperation and the CPLP Executive Secretariat"should be both a challenge and a strategic objective.

The last half of 2015 was clearly marked by the approval of the framework of the "2030 Agenda for Sustainable Development " by the Seventh United Nations General Assembly (UNGA) in September in New York. It demonstrated a strong political commitment towards the eradication of extreme poverty, in all its forms and dimensions, through 2030. In this sense, the year 2015 will go down in history as the year of defining of 17 Goals of Sustainable Development. This is a new action agenda that builds on progress and lessons learned from the 8 Millennium Development Goals, between 2000 and 2015. As we all know, this global agenda is the result of joint work of governments and citizens around the world to create a new global model to end poverty, promote prosperity and the well-being of all, protect the environment and combat climate change.

It is recalled that this agenda came in the wake of renewed hope that the arrival of the new millennium stressed, with the introduction in the international system of development cooperation of a comprehensive set of recommendations and principles which changed the gravitational axis of the international relations system, focusing on processes related to human development measures. The awareness on the part of world leaders that it was necessary to take in hand the presentation últimos cinco anos, alargou o leque das suas intervenções e se harmonizou de forma crescente com as prioridades de desenvolvimento dos Estados-membros, deu cumprimento à Declaração Constitutiva da CPLP. Tal dinamismo é evidenciado pela realização de mais de 15 reuniões ministeriais setoriais em diferentes domínios de intervenção.

Efetivamente, os últimos anos de execução do Plano Indicativo de Cooperação da CPLP (PIC) parecem demonstrar uma dinâmica positiva e um reforço da importância estratégica associada ao pilar de cooperação enquanto instrumento operacional e de diálogo político no seio da Comunidade. Esta dinâmica parece ser acompanhada pela crescente visibilidade e reconhecimento do papel da CPLP em domínios de cooperação como a Saúde, Segurança Alimentar e Nutricional (SAN), Trabalho e Assuntos Sociais (designadamente no domínio da luta contra o trabalho infantil), Direitos Humanos, Mares e Energia. No entanto, nota-se que os progressos registados foram assimétricos quer ao nível das áreas técnicas, quer no que respeita à apropriação e reforço da responsabilidade conjunta dos Estados membros da CPLP quanto à agenda e instrumentos comunitários aprovados.

Apesar do amadurecimento da capacidade de intervenção dos Pontos Focais de Cooperação (PFC), será necessária uma maior estabilização dos mecanismos de coordenação, articulação e harmonização de agendas com os pontos focais das Reuniões Ministeriais Setoriais e, consequente, ligação aos respetivos Secretariados Técnicos Permanentes (StP). O esforço de diálogo a promover em sede de Reuniões Ministeriais Setoriais, do Comité de Concertação Permanente, da Reunião dos Pontos Focais de Cooperação e do Secretariado Executivo da CPLP deverá ser, simultaneamente, um desafio e um objetivo estratégico.

O último semestre de 2015 foi claramente marcado pela aprovação, em setembro, da "Agenda 2030 para o Desenvolvimento Sustentável - transformando o nosso Mundo", no âmbito da 70a Assembleia Geral das Nações Unidas (AGNU), demonstrando um compromisso político impar para a erradicação da pobreza extrema, em todas as suas formas e dimensões, até 2030. Neste sentido, o ano de 2015 ficará na História como o ano da definição dos 17 Objetivos de Desenvolvimento Sustentável. Trata-se de uma nova agenda de ação que se baseia nos progressos e lições aprendidas com os 8 Objetivos de Desenvolvimento do Milénio, entre 2000 e 2015.

Como se sabe, esta agenda global é fruto do trabalho conjunto de governos e cidadãos de todo o mundo para criar um novo modelo global para acabar com a pobreza, promover a prosperidade e o bem-estar de todos, 
of measures and the definition of specific objectives to seek to overcome situations of shortage occurring since the late 60 's led to the organization of the Millennium Summit, held at the United Nations, in New York, between September 6-8, 2000. On that occasion the Millennium Development Goals (MDGs) were presented and Kofi Annan's Millennium Declaration adopted.

Thus, the 2030 Agenda for Sustainable Development seeks to achieve in the spectrum of successes and setbacks that formatted templates and development policies of the last decade and a half.

In the particular context of the CPLP, the adoption of the document "co-operation in CPLP - post 2015 strategic vision", in July 2015, demonstrated the maturity of the debate on the dynamics of the community's development cooperation and an important effort of coordination and consultation.

The option of the CPLP in acting on the basis of sectorial cooperative strategic plans in areas highly relevant to the sustainable development process of the community, of which Food Safety and Nutrition, Health, Environment, Education, Tourism and Oceans are only examples, allowed the consolidation of the image of a modern and credible CPLP, increasingly sought in the establishment of virtuous international partnerships. Geopolitical and geostrategic gains emerging from this strategy are still to be completely explored, and could be decisive to the affirmation of the potential of the community.

Just as an example let us consider CPLP's intervention in the area of food safety and nutrition and health, sectors in which the organization has been cited by institutions such as the World Bank and the FAO as an example of good practices and with progressive capacity to influence the international agenda.

In some measure, the CPLP has pioneered the introduction of methodologies and procedures, particularly as regards the creation of knowledge, best practices networks and resources sharing. In the wake of the conclusions of the $3^{\text {rd }}$ high level Forum on Aid Effectiveness, known as Accra Forum, held in September 2008, the adoption of a concept of North-South-South and Trilateral cooperation has been tested within the CPLP since 2009 with some success.

During the last decade, but particularly in the last five years, a significant increase in terms of trade, investment and cooperation between the countries of the socalled South ${ }^{1}$ could be seen. The potential offered by

\footnotetext{
${ }^{1}$ We should make it clear that this description does not match the name of the geographical South, but the classical Division of Theory of underdevelopment, which separated the developed countries (international cooperation donors) of developing countries (recipient countries of development cooperation), North and South.
}

proteger o ambiente e combater as alterações climáticas.

Recorde-se que esta agenda surge no seguimento do renovar de esperança que a chegada do novo milénio vincou, com a introdução no Sistema Internacional de Cooperação para o Desenvolvimento, de um vasto conjunto de recomendações e princípios que alteraram o eixo gravitacional do sistema de Relações Internacionais, centrando-o em processos ligados às chamadas medidas Desenvolvimento Humano. Foi a tomada de consciência por parte dos líderes mundiais de que era necessário tomar em mãos a apresentação de medidas e a definição de objetivos concretos para procurar ultrapassar situações de carência verificadas desde final dos anos 60 anos do século passado, que conduziu à realização da Cimeira do Milénio, realizada, nas Nações Unidas, em Nova Iorque, entre 6 e 8 de Setembro de 2000, da qual sairia o enunciado dos chamados Objetivos de Desenvolvimento do Milénio (ODM) e a consequente apresentação, pelo então Secretário-Geral das Nações Unidas, Kofi Annan, do "Road Map" tendo em vista a adoção da "Declaração do Milénio".

Assim, a Agenda 2030 para o Desenvolvimento Sustentável, procura concretizar-se no espetro dos sucessos e insucessos que formataram os modelos e políticas de desenvolvimento da última década e meia.

No contexto muito particular da CPLP, a aprovação do documento "Cooperação na CPLP - Uma visão estratégica no Pós 2015", em julho de 2015, demostrou o amadurecimento do debate sobre as dinâmicas de cooperação da Comunidade e um importante esforço de coordenação e concertação num cenário que irá exigir a identificação de novas modalidades de atuação e fontes de recursos.

A opção da CPLP em atuar com base em Planos Estratégicos de Cooperação Setorial em domínios altamente relevantes para o processo de desenvolvimento sustentável da Comunidade, de que as áreas da Segurança Alimentar e Nutricional, Saúde, Ambiente, Educação, Turismo e Oceanos são apenas exemplos, permitiu consolidar a imagem de uma CPLP moderna, credível e procurada de forma crescente para o estabelecimento de parcerias internacionais que se pretendem virtuosas. Daqui têm resultado ganhos, ainda não completamente explorados, que podem ser potenciados para uma afirmação decisiva do potencial geopolítico e geoestratégico da Comunidade.

A título meramente ilustrativo, refira-se o caso da intervenção da CPLP na área da Segurança Alimentar e Nutricional e Saúde, setores em que a organização é apresentada por instituições como o Banco Mundial e a FAO como um exemplo de boas práticas e com capacidade progressiva de influência da agenda internacional. 
South-South cooperation is today well acknowledged. The significant increase of political and economic dynamics between the so-called BRIC (Brazil, Russia, China and India $)^{2}$ is one of the reasons that explain these dynamics. Based on the principle of mutual benefit on South-South cooperation, there are no clear dividing lines between interventions which have development, conditionality and trade assistance as their purpose. These dynamics encompass substantial amounts of funding and donations as well as training and support to institutional capacity building.

Nonetheless, despite the positive assessment made by beneficiaries and the clear impact of these interventions, the evaluation in accordance with the criteria usually applied to Official Development Assistance (ODA) and subscribed by the principles of the Development Assistance Committee (DAC) of the Organisation for Economic Co-operation and Development (OECD) has not been possible and has been pending since the Busan Forum held in November 2011.

Defenders and promoters of the logic of South-South cooperation repeatedly state that this approach enables beneficiaries to identify priorities and needs more correctly in the context of their development processes, an option that in the view of these agents does not happen with North-South cooperation. Therefore questions on issues such as effectiveness, ownership and sustainability are essential, particularly under context of the new 2030 Agenda for sustainable development.

Taking into consideration the recent reports of multilateral organizations and the table of available indicators, progress in human and sustainable development continues at an exasperatingly slow pace. Some donors have continued to call for better governance in the support granted, and many beneficiaries felt that despite being generous, those contributions are not enough. However, the most open-minded have no fears in saying that what is lacking is political commitment of the entire international community, including those who should be more in compliance with the long announced commitments. The attempt to involve new actors in the development process, with calls for the establishment of public-private partnerships and private sector responsibility, is a new attempt to obtain resources in a particularly demanding geopolitical context.

The current situation is marked by a triple crisis - a crisis of global governance affecting more seriously developing countries. This crisis is financial, environmental and food and nutritional security.

Developing countries have been witnessing a drop in

\footnotetext{
${ }^{2}$ To this group of countries joined, 14 April 2011, during the third BRIC Summit held in Sanya, in the Chinese province of Hainan, South Africa.
}

Com efeito, em alguma medida, a CPLP tem sido percursora na introdução precoce de metodologias e procedimentos, particularmente no que se refere à criação de redes de saber para partilha de boas praticas, recursos e conhecimento. Na senda daquilo que foram as conclusões do III Fórum de Alto Nível sobre a Eficácia da Ajuda, conhecido como Fórum de Accra, realizado em setembro de 2008, a adoção de um conceito de cooperação Norte-Sul-Sul e Trilateral vem sendo testado no espaço da CPLP, desde 2009, com algum sucesso.

Durante a última década, mas muito particularmente nos últimos cinco anos, foi possível constatar um aumento muito significativo em termos de comércio, investimento e cooperação entre os países do chamado $\mathrm{Sul}^{1}$.

É hoje indiscutível o potencial que a Cooperação Sul-Sul oferece e, para essa perceção, muito tem contribuído o aumento muito significativo da dinâmica política $\mathrm{e}$ económica verificada entre os chamados BRIC (Brasil, Rússia, China e Índia) ${ }^{2}$. Tendo por base o princípio do mútuo benefício, na cooperação Sul-Sul, não existem linhas divisórias claras entre intervenções que tenham por objeto o desenvolvimento, a condicionalidade e intervenções comerciais. Esta ação envolve montantes substanciais de financiamento e donativos bem como formação e apoio à capacitação institucional.

Não obstante, apesar da avaliação positiva que dela fazem os beneficiários e do impacto destas intervenções ser evidente, não foi possível, até ao momento, avaliar estas ações com os critérios habitualmente aplicados à Ajuda Pública ao Desenvolvimento (APD) e princípios subscritos pelo do Comité de Ajuda ao Desenvolvimento (CAD), da Organização para a Cooperação e Desenvolvimento Económico (OCDE), processo de conformação que ainda decorre desde o Fórum de Busan, realizado em novembro de 2011.

Os defensores e promotores das lógicas de cooperação Sul-Sul referem, reiteradamente, que esta abordagem possibilita que as prioridades e necessidades sejam definidas e identificadas pelos beneficiários no contexto dos seus processos de desenvolvimento, o que, na ótica destes agentes, não acontece com a cooperação Norte-Sul, que utiliza uma perspetiva de resolução de um dado problema sem que tal abordagem seja encarada como uma oportunidade para o futuro. Como tal, surgem questões relativas à eficácia, apropriação e sus-

${ }^{1}$ Convirá precisar que esta designação não corresponde à designação do Sul geográfico, mas sim à divisão clássica da Teoria do Subdesenvolvimento, que separava países desenvolvidos (doadores de cooperação internacional) de países em desenvolvimento, (países beneficiários de cooperação para o desenvolvimento), em função de Norte e Sul.

${ }^{2}$ A este grupo de países juntou-se, a 14 de Abril de 2011, durante a terceira cimeira dos BRIC, realizada em Sanya, na Província chinesa de Hainan, a África do Sul. 
international prices of raw materials for essential goods that they produce. This is reflected in the reduction of export prices, with influence on tax collection and consequent effects on job creation and social protection systems, combined with a sharp drop in workers' remittances. These factors result in extremely serious consequences on disposable income, with harmful effects on ensuring adequate food security and nutrition. The financial crisis is joined by an environmental crisis caused by climate change, with particularly worrying effects such as the increase in extreme weather events (droughts and floods) triggering devastating consequences. This is also crucial for food security and nutrition as it is closely linked with food scarcity and the consequent increase in food prices causing phenomena of malnutrition, hunger and the vanishing of rural markets.

All these factors have implications in multilateral cooperation and consequent allocation of official development assistance to implement the 2030 Agenda, including committing as a human right the human right to adequate food (HRAF). It is known that the large-scale deprivation of human rights may ultimately endanger gains achieved in terms of peace and security, a situation which is particularly unsettling in post-conflict contexts or regions of chronic instability. Too, for many countries this situation can cause important setbacks in the achievement of development progress, and CPLP countries are no strangers to this context.

Knowing that CPLP member States are not immune to the crisis, despite the different degree of vulnerability and resilience characterising the community, they were encouraged to strengthen the strong ties already in place, projecting a cooperation strategy with mutual benefit and serving as an opportunity for the future. The strategy aims at joining the strengths of the NorthSouth-South cooperation, the use of know-how, tested best practices, appropriate technologies and a sustained and sustainable approach.

The future areas of cooperation for new CPLP may boost its dynamism and capacity to influence national and international agendas in the coming years. The potential for cooperative, cross-cutting and inter-sector approaches inherent in sectors such as Food Security, Health, Education, Science and Technology, Energy, Oceans, Youth, Human Rights, Education for Development and Citizenship, coupled with innovative practices of triangular cooperation, will give the CPLP the dimension of multilateral actor to which we all aspire, if properly framed and observed. However, in this picture there is an inescapable challenge. CPLP will have to continue to be committed and engaged in an effort of institutional capacity building and development of its tentabilidade da Cooperação para o Desenvolvimento, particularmente no âmbito da nova Agenda 2030 para o desenvolvimento sustentável.

Pelo quadro dos indicadores disponíveis e tendo por base os mais recentes relatórios da generalidade das organizações multilaterais, os progressos no desenvolvimento humano e sustentável continuam a fazer-se notar a um ritmo exasperadamente lento. Note-se que certos doadores continuaram a apelar a melhor governação nos apoios concedidos e muitos beneficiários consideraram que, apesar de generosos, esses apoios não chegam. Porém, os mais esclarecidos não têm dúvidas em afirmar que o que falta é compromisso político de toda a comunidade internacional, nomeadamente daqueles que mais podem, no cumprimento das dotações há muito anunciadas. A tentativa de envolvimento de novos atores no processo de desenvolvimento, com apelo constituição de parcerias público-privadas e à responsabilização do setor privado, é uma nova tentativa de conseguir recursos num contexto geopolítico particularmente exigente. A conjuntura atual é marcada por uma crise tripla - uma crise global de governança, que, de forma mais evidente, afeta os Países em Desenvolvimento. Esta crise faz-se sentir a nível financeiro, ambiental e de segurança alimentar e nutricional. Os Países em Desenvolvimento vêm assistindo a uma quebra internacional nos preços das matérias-primas de bens essenciais de que são produtores, o que se reflete na redução dos preços das exportações, com efeitos na coleta fiscal e consequente efeito na criação de emprego e de sistemas de proteção social, a que se junta, ainda, uma quebra acentuada das remessas de emigrantes. Tudo isto projeta consequências gravíssimas no rendimento disponível com efeitos perniciosos na garantia de uma sustentabilidade alimentar e nutricional adequada. Como se não bastasse, à crise financeira, junta-se também uma crise ambiental, provocada pelas alterações climáticas, com efeitos particularmente preocupantes como por exemplo o aumento de fenómenos climáticos extremos (secas e inundações) com consequências devastadoras. Por seu turno, a crise ambiental, encontra-se muito ligada uma crise de cariz alimentar e nutricional, a qual faz sentir os seus efeitos em termos da crescente escassez de bens alimentares com consequente aumento dos preços dos alimentos, o que provoca fenómenos de malnutrição, fome e ainda uma diminuição no incentivo à criação de mercados rurais.

Todos estes fatores têm implicações na cooperação multilateral e na consequente atribuição de fluxos para Ajuda Pública ao Desenvolvimento para concretização da Agenda 2030, designadamente comprometendo Direitos Humanos como o Direito Humano à Alimentação Adequada (DHAA). Ora, como se sabe, a privação em 
human potential. Only then will it be possible to give substance to the challenges that allow us to look to the future.

The theme related to food and nutrition security in its aspects of HRAF as a structural vector of the development process of our member States could contribute to this end. Therefore, we should emphasise that this is a sector where the horizontality is obvious and where the interest and capacity of multilateral intervention of the CPLP can be done in parallel with the preservation of the necessary bilateral and strategic interests of our member States and in addition to what is already performed by other actors of multilateral nature. In fact, the guideline approved in the frame of "CPLP strategic vision for Development Cooperation after Bissau", approved in 2009, has already foreseen that approach.

The Food and Nutritional Security Strategy of CPLP (ESAN-CPLP), approved in 2011, is a concrete and effective instrument for increasing the levels of human development in CPLP member States. But the identification and implementation of this program in the context of CPLP requires consultation, active participation and engagement of all stakeholders involved in the process so that this dimension can have sustainable impact on the development of our community. To make this theme sustainable, CPLP should further promote an overview that allows the adoption of integrated and complementary actions and policies, linking the CPLP agenda to the international agenda and cross-cutting issues such as education, health, environment, energy, economy, youth, human rights, development and citizenship education. So, it would be interesting to (a) explore opportunities that allow addressing the themes in a horizontal dimension, promoting coordination and complementarity of food and nutritional security with other sectoral policies and other international actors and (b) promote networking, dialogue and coordination between the Food and Nutritional Security Council of CPLP (CONSAN-CPLP) with other Community coordinating bodies and structures.

The vision of ESAN-CPLP is based on a "community of countries with a healthy and active human capital, free of hunger and poverty, in the context of progressive realization of the human right to adequate food and respect for national sovereignty" and it aims to the establishment of HRAF as a way of contributing to the eradication of hunger and poverty at Community level by strengthening coordination between member States and improving the governance policies of food and nutritional security programmes".

The principles of ESAN-CPLP are based on placing the highest political priority to the fight against hunger and malnutrition in our countries; the existence of grande escala de direitos humanos pode, em última instância, fazer perigar ganhos alcançados a nível da paz e da segurança - situação que se afigura como particularmente inquietante em contextos de pós-conflito ou de instabilidade crónica. Por outro lado, esta situação representa, para muitos países, retrocessos importantes no que concerne à consecução dos progressos do desenvolvimento, não sendo os países que integram a CPLP estranhos a este contexto.

Sabendo que os Estados membros da CPLP não estão imunes à crise, não obstante o diferente grau de vulnerabilidade e de resiliência que os caracteriza, foi a Comunidade estimulada a estreitar os fortes laços unem os seus Estados, num exercício de cooperação com vantagens mútuas, baseado em estímulos positivos que juntem os pontos fortes da cooperação Norte-Sul-Sul, utilizando o saber-fazer, as tecnologias adequadas ao contexto dos parceiros, uma abordagem sustentada e o desenho de uma intervenção que sirva como uma oportunidade para o futuro.

As novas áreas de cooperação para o futuro poderão conferir à CPLP um reforço do seu dinamismo e capacidade de influência das agendas nacionais e internacionais dos próximos anos. O potencial de cooperação, a transversalidade e intersetorialidade inerente a setores como a Segurança Alimentar e Nutricional, Saúde, Educação, Ciência e Tecnologia, Energia, os Oceanos, a Juventude, os Direitos Humanos, a Educação para a Cidadania e o Desenvolvimento, aliados a práticas inovadoras de cooperação triangular, se corretamente enquadrados e observados permitirão conferir à CPLP a dimensão de ator multilateral que todos ambicionamos. Porém, em todo este quadro, existe um desafio incontornável! A CPLP terá que continuar a apostar, de forma empenhada e comprometida, num esforço de capacitação institucional e valorização do seu potencial humano. Só assim será possível dar substância aos desafios que nos interpelam a olhar para o futuro.

A temática ligada à Segurança Alimentar e Nutricional, na sua vertente de DHAA, enquanto vetor estruturante do processo de desenvolvimento dos nossos Estados membros, poderá contribuir para esse fim. Desde logo, convirá realçar que se trata de um setor onde a transversalidade é óbvia e onde o interesse e capacidade de intervenção multilateral da CPLP se poderá fazer em paralelo com a preservação dos necessários interesses estratégicos bilaterais e em complemento daquilo que é já realizado por outros atores de cariz multilateral e de que os nossos Estados membros já beneficiam. Aliás, na linha de orientação aprovada pela Visão Estratégica de Cooperação da CPLP pós-Bissau, aprovada em 2009.

A Estratégia de Segurança Alimentar e Nutricional da CPLP (ESAN-CPLP), aprovada em 2011, é um instru- 
National Food Security and Nutrition Strategies and several previous commitments namely: the five principles of the World Food Summit of 2009; the Volunteer Guidelines for the progressive realization of the right to adequate food; and the priorities considered in policies and programmes for food and nutritional security of the regional integration spaces where CPLP member States are located.

The first priority of ESAN-CPLP is strengthening food security and nutrition governance at Community level. The second is addressed to the immediate support to the most vulnerable groups, in particular women and children, looking for some partnerships with specialised agencies of the United Nations. The third priority is focused on increasing the availability of food based on internal promotion and support of small farmers and fishermen, promoting sustainable production models and expanding the local diets.

For CPLP, the adoption of ESAN-CPLP should not be merely a technical exercise of development cooperation. It should, above all, be considered a political and strategic design, crucial to the development of its member States, which will mark the Organization in the near future. The Strategy could contribute to the creation of a global partnership and comprehensive mechanism on agriculture, food and nutrition, involving actors from civil society, private sector and development cooperation partners like the United Nations specialized agencies, international financing institutions and regional oriented organisations.

The presentation of ESAN-CPLP on October 18, 2011 to the 37th Session of the Committee on World Food Security (CFS) and the subsequent recognition of this instrument by development partners such as the European Union confirmed the priority given by CPLP to the fight against hunger and malnutrition and to the strengthening of the governance system of FSN.

This result seems to have been achieved with the decision of the Conference of Heads of State and Government of CPLP (CCEG), held in Dili in July 2014, particularly within the framework of the "resolution on the continuation, until 2025, of food security and nutrition theme on the Agenda of the CPLP". The resolution solidified the theme "food and nutritional security" in the agenda of the presidencies of CPLP and the CCEG until 2025. This agenda reframing is particularly important for CPLP since it meets the founding principles of the Organization, creasing a clear need of jointly supporting those who are most disadvantaged and that are in the forefront when it comes to eradicating hunger and poverty at CPLP.

Since the adoption of ESAN-CPLP in 2011, the ad- mento concreto e efetivo para incrementar os níveis de desenvolvimento humano dos Estados membros da CPLP. Mas a identificação e implementação deste programa no contexto da CPLP requer a participação concertada, ativa e empenhada de todos os detentores de interesse envolvidos no processo para que esta dimensão possa ser devidamente apropriada, numa lógica de sustentabilidade futura e de desenvolvimento da nossa Comunidade. Para tornar este tema sustentável, a CPLP deverá continuar a promover uma visão de conjunto que possibilite a adoção de ações e politicas integradas e complementares, vinculando a agenda da CPLP à agenda internacional e a temas transversais como a educação, a saúde, o ambiente, a energia, a economia, a juventude, os direitos humanos, a educação para o desenvolvimento e cidadania, por exemplo. Assim, seria interessante (a) explorar oportunidades que permitam abordar os temas numa dimensão transversal, promovendo a coordenação e a complementaridade da segurança alimentar e nutricional com outras políticas setoriais e outros atores internacionais e (b) fomentar o trabalho em rede, promovendo o diálogo e articulação entre o Conselho de Segurança Alimentar e Nutricional da CPLP (CONSAN-CPLP) com outros órgãos coordenadores e superiores da CPLP.

A visão da ESAN-CPLP assenta numa " Comunidade de países com um capital humano saudável e ativo, livre da fome e da pobreza, num quadro de realização progressiva do direito humano à alimentação adequada e respeito pela soberania nacional" e o seu objetivo passa pelo estabelecimento do DHAA, enquanto forma de contribuir para a erradicação da fome e da pobreza na Comunidade, através do reforço da coordenação entre os Estados membros e da maior governança das políticas e programas setoriais de segurança alimentar e nutricional".

As bases da ESAN-CPLP assentam na máxima prioridade política à luta contra a fome e a malnutrição nos nossos países; à existência de Estratégias nacionais de Segurança Alimentar e Nutricional e vários compromissos anteriormente assumidos, nomeadamente: os cinco princípios da Cimeira Mundial de Alimentação de 2009, as Diretrizes Voluntarias para a Realização Progressiva do Direito à Alimentação Adequada e as prioridades consideradas nas políticas e programas de segurança alimentar e nutricional dos espaços de integração regional regionais onde se inserem os Estados membros da CPLP.

A primeira prioridade da ESAN-CPLP será, pois, o fortalecimento da governança da segurança alimentar e nutricional a nível comunitário. A segunda será dirigida ao apoio imediato aos grupos mais vulneráveis em particular às mulheres e crianças, procurando algumas 
vances recorded in CPLP regarding cooperation on FSN are clear.

The following improvements are not exhaustive:

- An FAO liaison office was installed at CPLP headquarters in Lisbon;

- The implementation of ESAN-CPLP was made according to a plan of activities agreed between all the actors;

- The essential publications of FAO on the HRAF were translated into Portuguese language;

- A working group was set up under the theme of family agriculture;

- Steps have been taken in building capacities for family farming, food and nutritional security and HRAF, by performing various diagnoses and construction of participatory processes of consultation and debate;

- The involvement of civil society, universities, research centres, business confederation and parliamentarians in the implementation of ESAN-CPLP is today a reality;

- The CPLP is the first regional organization to develop an exercise in setting guidelines for agriculture and to start the definition of the family farmer category; - It was possible to strengthen ties with the Committee on World Food Security (CFS), ensuring a consistent presence in that body since its 37 th session;

- The CPLP is considered to be the first region in the implementation of the overall strategic Framework of the CFS;

- It was possible to activate the mechanism CONSANCPLP and replicate their philosophy in four States of the Community that have or will in the short term FSN Councils (Brazil, Cape Verde, Guinea-Bissau, Sao Tome and Principe, Timor-Leste).

ESAN-CPLP seeks to contribute effectively to the strengthening of multilateral cooperation in FSN, materialising in concerted actions aimed at strengthening the institutional capacity of FSN public systems of CPLP member States. Thus, many challenges arise:

- The existence of FSN Councils in all countries and, if possible, with coherent institutional architecture with the CONSAN-CPLP;

- Capacity-building at various levels for greater understanding of contemporary FSN challenges;

- The need for compliance with budgets, monetary commitments and fundraising;

- Creation and streamlining of a working group on health and nutrition.

The ESAN-CPLP achieved new development cooperation logics and allowed the introduction of new indicators of coherence, relevance and ownership, and this has been one of the fundamental vectors that have aroused the attention of various development partners. parcerias com agências especializadas das Nações Unidas. A terceira prioridade encontra-se focada no aumento da disponibilidade interna de alimentos com base no fomento e dinamização dos pequenos produtores agrícolas e pescadores, promovendo modelos de produção sustentáveis e ampliando as dietas locais.

Para a CPLP, a aprovação da ESAN-CPLP não deveria constituir meramente um exercício técnico de cooperação para o desenvolvimento. Deveria, acima de tudo, ser considerado um desígnio político e estratégico, determinante para o processo de desenvolvimento dos seus Estados membros, que irá marcar a organização nos próximos tempos, contribuindo para que se possa criar um mecanismo de parceria global e abrangente sobre a agricultura, alimentação e nutrição, o qual deverá envolver atores oriundos da sociedade civil e do setor privado, dos parceiros de cooperação, das organizações especializadas das Nações Unidas, das instituições internacionais de financiamento e das organizações de cariz regional.

A apresentação da ESAN-CPLP, em 18 de Outubro de 2011, à $37^{\mathrm{a}}$ Sessão do Comité Mundial de Segurança Alimentar e o posterior reconhecimento deste instrumento por parceiros de desenvolvimento como a União Europeia, vêm reconhecer o esforço da CPLP na constituição desta parceria global e confirmar a máxima prioridade política dada pela CPLP à luta contra a fome e a malnutrição bem como ao fortalecimento da governança da segurança alimentar e nutricional e, quem sabe, apresentando exemplos de boas praticas que extravasem o espaço da Comunidade.

Este resultado parece ter sido conseguido com a decisão da X Conferência de Chefes de Estado e de Governo da CPLP (CCEG), de julho de 2014, em Díli, nomeadamente no âmbito da "Resolução sobre a Continuidade, até 2025, do Tema Segurança Alimentar e Nutricional na Agenda da CPLP", que consagrou o tema "Segurança Alimentar e Nutricional" nas agendas das presidências da CPLP e das CCEG até 2025. Este recentramento da agenda é particularmente importante para a CPLP uma vez que vai ao encontro dos princípios fundadores da organização, vincando uma clara necessidade de solidariamente se apoiarem aqueles que são mais desfavorecidos e os primeiros em quem se deve pensar quando se fala em erradicação da fome e da pobreza na CPLP. São hoje inequívocos os avanços verificados na CPLP na vertente da cooperação em SAN, desde a aprovação, em 2011, da ESAN-CPLP. De forma não exaustiva destacam-se os seguintes avanços:

- Foi instalado um escritório de ligação com a Organização das Nações Unidas para a Agricultura e Alimentação (FAO), na sede da CPLP, em Lisboa;

- A implementação da ESAN-CPLP é feita de acordo 
There are still some threats facing this Community. Those pressures prevent the Community from being able to exert a functional power that could be more active and recognized in the field of international relations. In our analysis we have considered only internal threats to the Organization and not others derived from the environment in which it operates and relates. They are the following:

- The assertion of a more affirmative political will by the member States in the process of growth and consolidation of CPLP project. There are some reasons for that to happen: a) all the different international priorities, sometimes antagonistic, of the CPLP member States of the CPLP, in particular within the framework of the commitments made in other contexts; b) the mechanism of decision by consensus, indicating all member States are equal to each other, hampers more substantial advances in some dossiers; c) the insignificant financial contributions to the functioning budget of the executive body of the Organization and the failure of that commitment in comparison with other equivalent entities, and d) differentiated strategies in the process of development and growth as well as impairments in how these political and social models project its presence and ambitions in the Community;

- The non-identification of CPLP and its role by its citizens and by international partners, projecting a deficit of mutual knowledge of the various realities of CPLP for its citizens and even for most of their political leaders;

- The lack of credibility, sustainability and organizational capacity indicated of the CPLP by some international actors and other stakeholders.

Despite the threats above, we do think it is fair and appropriate to conclude that CPLP has the potential to be able to exercise its functional power in future, positioning itself as a very valid partner of international relations and to be taken in due account in the next twenty years. The manner in which the CPLP consecrates HRAF logic in its space will be decisive for that purpose.

\section{Conflict of interests}

The authors declare that there are no financial and/or personal relationships that could be viewed as presenting a potential conflict of interests. com um plano de atividades acordado entre todos os atores;

- Foram traduzidas para língua portuguesa as publicações essenciais da FAO sobre o DHAA;

- Foi constituído um Grupo de Trabalho subordinado ao tema da Agricultura Familiar;

- Foram dados passos na construção de capacidades para agricultura familiar, Segurança Alimentar e Nutricional e DHAA, através da realização de vários diagnósticos e construção de processos participativos de consulta e debate;

- Conseguiu-se o envolvimento da sociedade civil, universidades, centros de investigação, empresariado e parlamentares na implementação da ESAN-CPLP;

- A CPLP é a primeira organização de base regional a desenvolver um exercício de definição de diretrizes para a agricultura familiar e a iniciar a definição da categoria de agricultor familiar;

- Foi possível reforçar os laços com o Comité Mundial de Segurança Alimentar (CSA), assegurando uma presença consistente nesse órgão desde a sua $37^{\mathrm{a}}$ a Sessão; - A CPLP é considerada a primeira região na implementação do Quadro Estratégico Global do CSA;

- Foi possível ativar o mecanismo CONSAN-CPLP e replicar a sua filosofia em 4 Estados da Comunidade, que possuem ou possuirão a curto prazo, Conselhos de SAN (Brasil, Cabo Verde, Guiné-Bissau, São Tomé e Príncipe, Timor-Leste).

A ESAN-CPLP procura contribuir de forma efetiva para o fortalecimento da cooperação multilateral em SAN, materializando-se em ações concertadas que visam o reforço da capacidade institucional dos sistemas públicos de SAN dos Estados membros da CPLP. Por isso, muitos desafios se colocam ainda:

- A existência de Conselhos de SAN em todos os países e, se possível, com arquitetura institucional coerente com o CONSAN-CPLP;

- A construção de capacidades a vários níveis para maior entendimento sobre os desafios contemporâneos da SAN;

- A necessidade de cumprimento de orçamentos e captação de recursos;

- Criação e dinamização de um Grupo de Trabalho em Saúde e Nutrição.

A ESAN-CPLP conseguiu articular lógicas de cooperação que, sendo distintas entre si nos meios e filosofias operativas, permitiram introduzir novos indicadores de coerência, pertinência e apropriação das ações que projetou. E tem sido esse um dos vetores fundamentais que tem despertado a atenção de vários parceiros de desenvolvimento.

Apesar de tudo, algumas ameaças se colocam a esta Comunidade, impedindo-a de poder exercer um poder 
funcional que poderia ser mais ativo e reconhecido no plano das relações internacionais. Consideraremos na nossa análise ameaças internas à organização e não outras derivadas do meio em que se insere e relaciona. São elas as seguintes:

- A afirmação de uma vontade política mais declarada e afirmativa por parte dos Estados membros no processo de crescimento e consolidação do projeto CPLP. Para que tal possa acontecer, muito contribui, por exemplo, a) o conjunto das diferentes prioridades internacionais, por vezes antagónicas, dos Estados membros que compõem a CPLP, nomeadamente no quadro dos compromissos assumidos noutros contextos; b) O mecanismo da decisão por consenso que, apesar de não significar unanimidade e procurar indicar que todos os Estados membros são iguais entre si, impede avanços mais substanciais em alguns dossiês, c) as pouco significativas contribuições regulares para o funcionamento do órgão executivo da organização e o não cumprimento das mesmas por parte de alguns EM, quando comparadas com entidades de dimensão e potencial equivalente e d) estratégias diferenciadas nos processos de desenvolvimento e crescimento bem como imparidades na forma como esses modelos políticos e sociais projetam a sua presença e ambição na Comunidade; - A não identificação da CPLP e do seu papel pelos seus cidadãos e pelos parceiros internacionais, projetando um deficit de conhecimento mútuo das diferentes realidades da CPLP pelos seus cidadãos e até por boa parte dos seus líderes políticos e o olhar desconfiado sobre a CPLP de alguns atores internacionais que lhe apontam a falta de credibilidade, sustentabilidade e capacidade organizativa;

Pela análise efetuada e, apesar das ameaças acima, pensamos ser justo e adequado concluir que a CPLP dispõe de potencial para poder exercer o seu poder funcional no futuro, posicionando-se como um parceiro de relações internacionais muito válido, de enorme capacidade, competente e a tomar em devida linha de conta nos próximos 20 anos. E para isso muito contribuirá a forma como a CPLP conseguir consagrar no seu espaço a lógica do Direito Humano a uma Alimentação Adequada.

\section{Conflito de Interesses}

Os autores declaram não existir qualquer relação pessoal ou financeira que possa ser entendida como representando um potencial conflito de interesses. 